\title{
DESIGN OF LED BASE BELL'S PALSY THERAPY DEVICE USING MIKROKONTROLLER ATMEGA 8535
}

\author{
Atika Hendryani ${ }^{1)}$, Mhd. Hestu Azhim ${ }^{1)}$ \\ ${ }^{1}$ Jurusan Teknik Elektromedik, Poltekkes Kemenkes Jakarta II, Jalan Hang Jebat III/F3 \\ Kebayoran Baru Jakarta 12120 \\ E-mail: atikahdy@gmail.com
}

Submited: 8 October 2018 ; Accepted: 9 October 2019

https://doi.org/10.36525/sanitas.2019.2

\begin{abstract}
Bell's Palsy is a disease that attacks the facial nerves to cause muscle paralysis on one side of the face, indicated by conditions one side of the face becomes stiff and difficult to move. Therapeutic devices are also very much needed to cure facial stiffness besides of giving medicines. One of the most widely used therapies is warm therapy, however, this therapy takes a long time and quite expensive too. This research proposed a simple and affordable bell's palsy therapy device use LED temperature heating media and a time controller based on the microcontroller ATMega 8535. The test is carried out at a time and temperature series, the result shows the circuit accuracy reaches $100 \%$ on a 15 -minutes test. Testing on temperature stability also showed achieving a stable temperature at $420 \mathrm{C}$ in the 15 minutes. Device function tests are only carried out at a time and temperature series, the patient safety test has not been carried out. So that it still needs to be improved in future studies, especially in safety mode.
\end{abstract}

Keywords: Bell's palsy, device therapy, LED therapy

\section{DESAIN ALAT TERAPI BELL'S PALSY BERBASIS LED MENGGUNAKAN MIKROKONTROLER ATMEGA 8535}

\begin{abstract}
ABSTRAK
Bell's Palsy adalah penyakit yang menyerang saraf wajah yang menyebabkan kelumpuhan otot pada satu sisi wajah, ditandai oleh kondisi satu sisi wajah menjadi kaku dan sulit bergerak. Alat terapi juga sangat dibutuhkan untuk menyembuhkan kekakuan wajah selain memberikan obat-obatan. Salah satu terapi yang paling banyak digunakan adalah terapi hangat, namun terapi ini membutuhkan waktu yang lama dan juga mahal. Penelitian ini mengusulkan perangkat terapi bell's palsy yang sederhana dan terjangkau menggunakan media pemanas suhu LED dan pengontrol waktu berbasis mikrokontroler ATMega 8535. Pengujian dilakukan pada rangkaian waktu dan suhu, hasilnya menunjukkan akurasi rangkaian mencapai $100 \%$ selama pengujian waktu 15 menit. Pengujian pada stabilitas suhu juga menunjukkan mencapai suhu yang stabil pada $42^{\circ} \mathrm{C}$ dalam 15 menit. Tes fungsi perangkat hanya dilakukan pada seri waktu dan suhu, uji keamanan pasien belum dilakukan. Sehingga hal itu masih perlu ditingkatkan pada penelitian selanjutnya, terutama dalam mode keselamatan dan keamanan pasien.
\end{abstract}

Kata kunci: Bell's palsy, alat terapi, terapi LED 


\section{PENDAHULUAN}

Bell's Palsy adalah penyakit yang menyerang saraf wajah yang menyebabkan kelumpuhan otot pada satu sisi wajah. Saraf yang lumpuh ini ditandai oleh kesulitan menggerakkan beberapa otot wajah, seperti mata tidak bisa menutup, tidak bisa berkedip, dan lain-lain.(1,2) Selain obat-obatan, terapi fisik juga sangat dibutuhkan untuk membantu mempercepat pemulihan pasien.(3) Dari sudut pandang medis, alat terapi wajah diharapkan dapat melakukan fungsi utamanya, yang mampu memberikan kehangatan untuk mengembalikan otot-otot di sekitar bibir dalam posisi normal seperti pada penderita bell's palsy.(4-6)

Ada beberapa jenis terapi yang biasa digunakan untuk bell's palsy termasuk sengatan listrik, terapi cahaya dan terapi panas. Studi terbaru telah membuktikan bahwa pasien dengan kelumpuhan wajah merespon positif terhadap perawatan fototerapi.(7) Fototerapi adalah penggunaan cahaya sebagai media terapeutik, di sisi lain, terapi panas atau termoterapi menggunakan suhu tertentu sebagai media terapeutik.(8) Cahaya sebagai media terapeutik telah lama digunakan bahkan ribuan tahun yang lalu di Mesir dan India, penggunaannya untuk pengobatan penyakit kulit seperti psoriasis, vitiligo, dan kanker.

Light Emitting Diode (LED) banyak digunakan sebagai sumber fototerapi, penelitian menunjukkan bahwa tidak ada risiko tinggi dalam penggunaan LED pada perangkat terapi. $(9,10)$ Terapi LED juga menunjukkan hasil yang baik pada pasien dengan Bell's palsy.(11-13) Won-Serk Kim (2011), membuktikan bahwa sistem fototerapi LED memiliki panjang gelombang dan kepadatan daya yang tepat serta kepadatan energi yang memadai sehingga sangat efektif dalam penyembuhan sel. [14]

Saat ini banyak perangkat terapi wajah telah dikembangkan termasuk terapi kejut listrik, terapi cahaya, dan terapi pemanasan.(14-16)Selain menggunakan sumber terapi yang berbeda, penelitian ini juga menciptakan banyak jenis konduktor yang digunakan pada pasien. Baird membuat perangkat terapi menggunakan bahan yang terbuat dari wadah plastik cetak injeksi. Kotak utama berisi pengaturan 36-72 LED pada papan sirkuit di dalam untuk memberikan pencahayaan. Beberapa LED dikonfigurasikan untuk memiliki kontak langsung dengan kulit atau jaringan pasien tanpa konduktor apa pun dan menerangi permukaan dan lapisan jaringan di bawahnya untuk merangsang fotodinamik sel. Adaptor 
daya AC ke DC menyediakan tegangan dan arus yang diperlukan untuk output dan umur optimal dioda pemancar cahaya. Tidak ada rangkaian penghitung waktu otomatis pada perangkat ini (17) Kipp menekankan pada perangkat portabel sehingga dapat dibawa seperti koper dari satu lokasi ke lokasi lain dan dapat digunakan untuk merawat berbagai bagian tubuh, seperti wajah, tangan, kaki, dan dada.(18) Dane Alexander, dkk membuat masker terapi untuk wajah menggunakan sumber panas dari LED. Kerugian dari penelitian ini adalah bahwa itu tidak khusus untuk bell palsy tetapi hanya untuk masalah kulit biasa. (19) Penelitian sebelumnya lebih memperhatikan perancangan alat dan konduktor. Sayangnya, para peneliti jarang menerapkan pilihan waktu terapi yang telah diprogram secara otomatis dalam perangkat sistem.

Kohli merancang sistem fototerapi dasar LED yang dapat diprogram yang menggunakan mikrokontroler TM4C123GH6PM yang diprogram untuk memungkinkan pemilihan berbagai parameter seperti frekuensi, panjang gelombang dan waktu pemaparan. Penelitian ini berhasil membuat desain fototerapi otomatis tetapi tidak membuat konduktor khusus untuk pasien.(20) Tujuan dari makalah ini adalah untuk membuat perangkat terapi palsy Bell otomatis yang aman, mudah, dan terjangkau bagi pasien.

Masalah dengan pasien Bell's palsy adalah mereka harus melakukan terapi secara teratur sehingga wajah mereka dapat kembali normal. Ini membutuhkan waktu yang lama dan biaya yang cukup mahal sehingga menyebabkan pasien enggan pergi ke rumah sakit untuk terapi. Tujuan dari penelitian ini adalah untuk membuat perangkat terapi bell's palsy yang aman dan terjangkau menggunakan media pemanas suhu LED.

\section{METODE PENELITIAN}

Spesifikasi sistem yang diusulkan adalah sebagai berikut: Tegangan suplai +5 Volt dan +12 Volt; Pengaturan waktu dirancang menggunakan hitungan mundur dalam menit dari 60 hingga 0 menit; gunakan 2 Dot-Matrix HD44780 LCD (Liquid Crystal Display) sebagai tampilan waktu dan suhu; sistem menggunakan Mikrokontroler ATMega 8535; gunakan LED Stripe dengan tegangan input $12 \mathrm{~V}$.

Gambar 1 menunjukkan arsitektur sistem yang diusulkan dalam artikel ini. Desain sistem terdiri dari 4 blok, blok 1 adalah rangkaian tombol yang fungsinya untuk memilih 
waktu dan suhu. Rangkaian tombol ini terhubung ke blok 2, mikrokontroler. Dalam blok ini, nilai waktu dan suhu yang diberikan akan diproses oleh mikrokontroler dan diteruskan ke blok 3 untuk menampilkan jumlah waktu dan suhu dan mengaktifkan blok 4, LED. Keempat blok mendapatkan sumber tegangan utama dari catu daya.

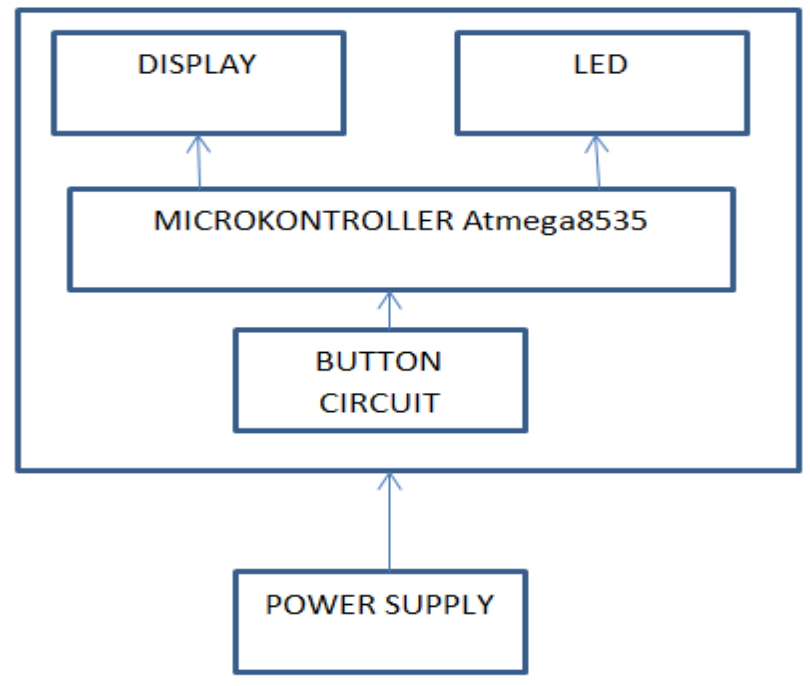

Gambar 1. Arsitektur Sistem Alat Terapi Bell's Palsy Berbasis LED

Pada gambar 2 mengilustrasikandiagram alir algoritma desain perangkat lunak unit mikrokontroler dari sistem alat terapi bell's palsy berbasis LED. Saat proram dijalankan maka fungsi utama menginisialisasi clock utama untuk mengoperasikan mikrokontroler. Ini juga memanggil fungsi untuk menentukan variabel waktu. Setelah variabel diatur maka akan menampilkan nilai waktu pada LCD. Ketika tombol START ditekan akan mengaktifkan rangkaian timer dan memulai waktu hitung mundur untuk terapi. Di sisi lain, ini juga mengaktifkan sirkuit LED sampai waktu yang ditentukan habis. 


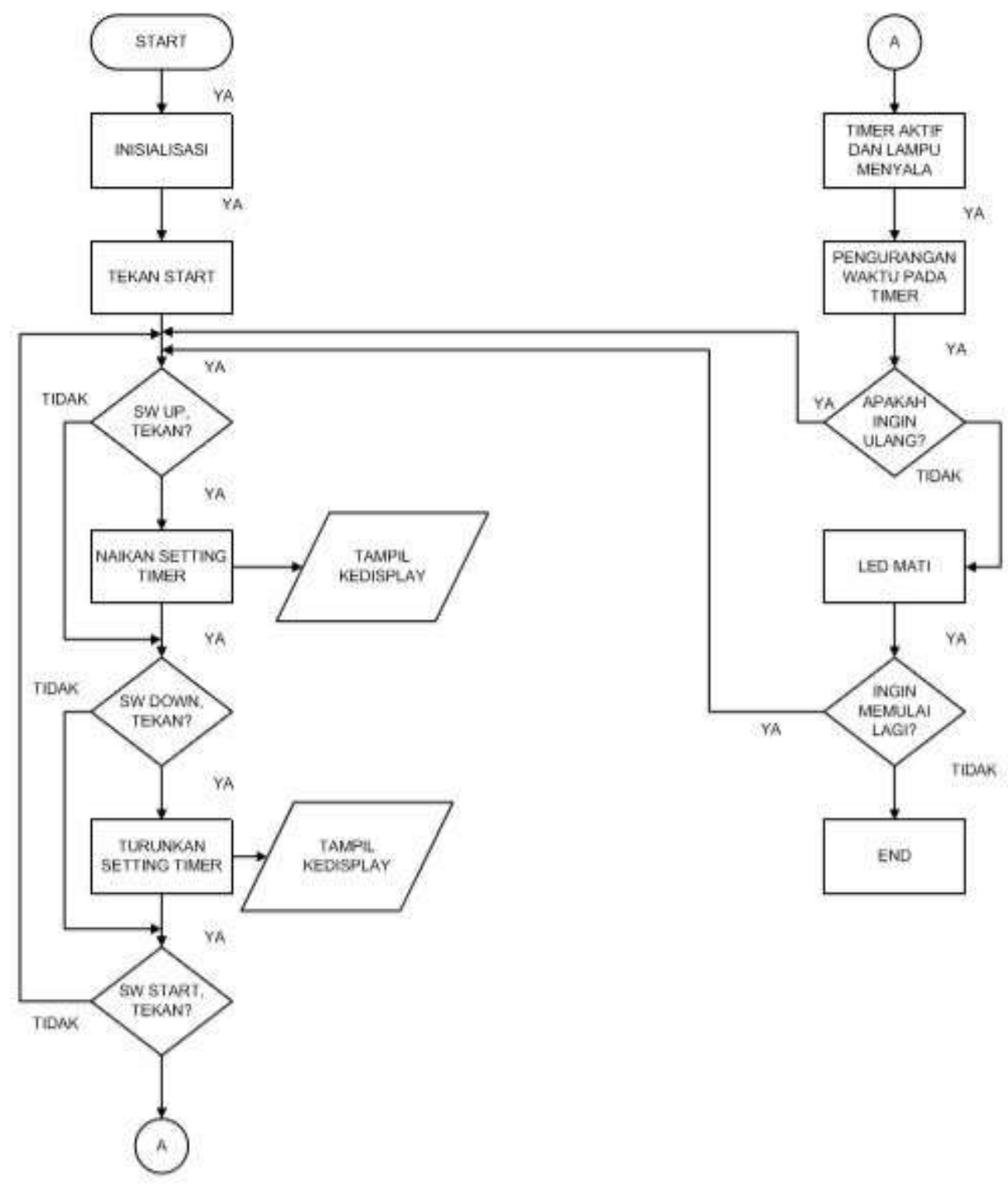

Gambar 2. Diagram Alur Algoritma Alat Terapi Bell's Palsy Berbasis LED

Gambar 4 menunjukkan skema PCB dari perangkat terapi bell's palsy berbasis LED , terdapat empat tombol pada rangkaian tombol, tombol yang digunakan dalam seri ini biasanya terbuka. Fungsi masing-masing tombol adalah sebagai berikut: Tombol UP/ DOWN untuk menentukan lamanya waktu pengoperasian peralatan yang dibutuhkan, 
tombol START untuk mengaktifkan sirkuit timer dan mengaktifkan LED, sehingga waktu akan mundur, tombol STOP untuk menghentikan timer dan mematikan LED. Blok mikrokontroler adalah aktor utama atau pengendali otak dalam rangkaian keseluruhan. Mikrokontroler ATMega8535 akan menjalankan pengaturan waktu dan LED. Output dari mikrokontroler AT8535 akan ditampilkan oleh LCD.

LCD yang digunakan dalam sistem ini adalah LCD (Liquid Crystal Display) DotMatrix HD44780 adalah salah satu jenis dot-matrix LCD dengan karakter 16x2 dan dikendalikan oleh pengontrol Hitachi HD44780, LCD ini digunakan untuk menampilkan waktu yang dipilih dan lamanya waktu operasi. LED Strip yang digunakan pada alat ini menghasilkan panas yang terus meningkat hingga maksimum $45^{\circ} \mathrm{C}$. LED Strip ini aman bersentuhan langsung dengan kulit karena ada gel sebagai perantara ke kulit. Durasi terapi dengan alat ini tergantung pada sensitivitas suhu kulit pasien, jenis penyakit yang diderita pasien.

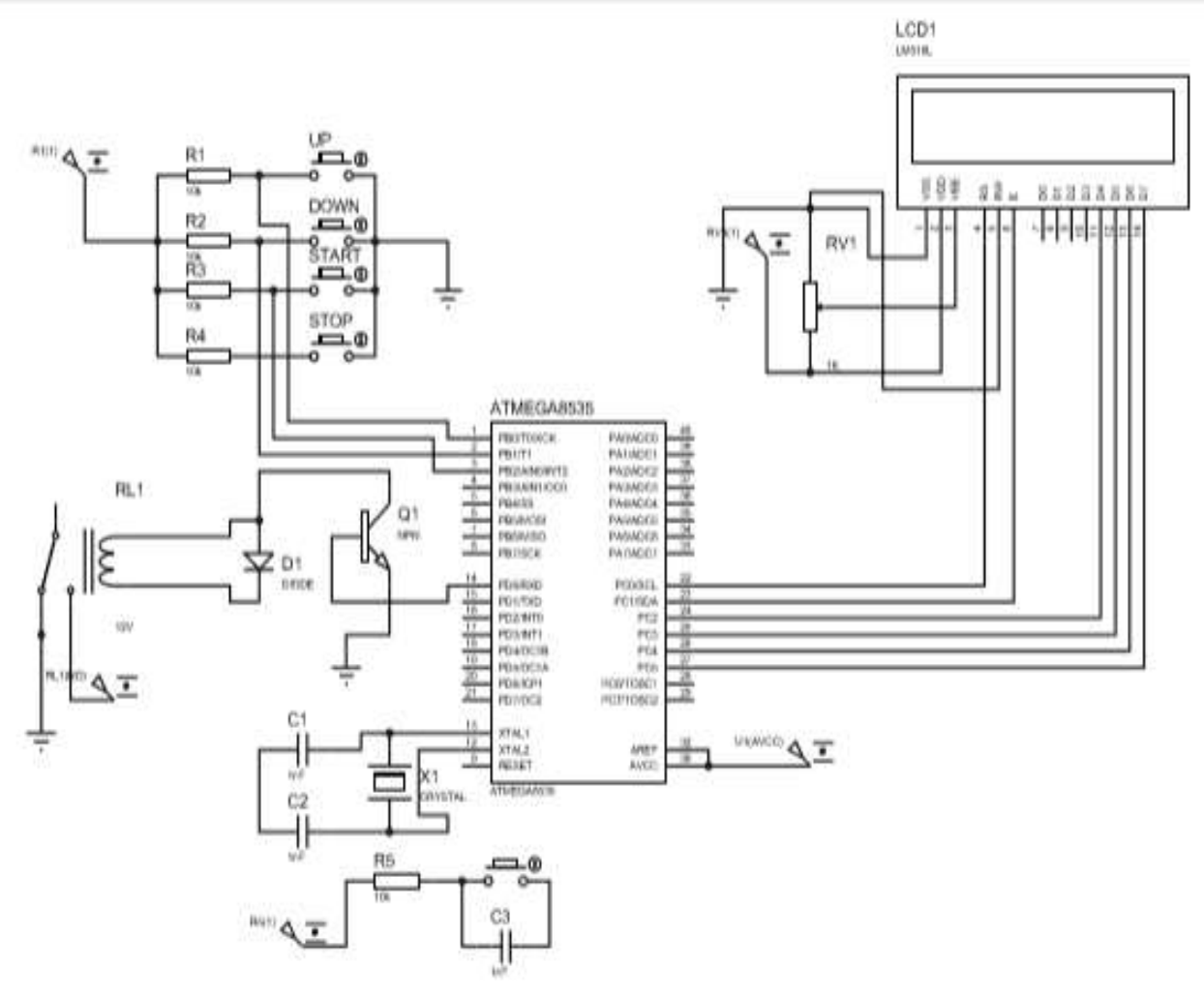

Gambar 3. Skema PCB Alat Terapi Bell's Palsy Berbasis LED 


\section{HASIL DAN PEMBAHASAN}

Media terapi yang digunakan dalam penelitian ini adalah strip LED yang terpasang pada masker. LED hanya ditempelkan di salah satu sisi kanan atau kiri bawah wajah. Ini berarti bahwa hanya bagian wajah yang bermasalah yang terkena sinar LED. Bagian kiri dan kanan dapat dipilih dengan menggerakkan pin LED yang terhubung ke kotak tombol. Masker terapi seperti yang ditunjukkan pada gambar 4 adalah bagian yang diterapkan pada wajah pasien, bagian ini akan melepaskan panas dari lampu LED. Panas yang dilepaskan dari LED akan merangsang sel-sel wajah pasien yang menderita kekakuan.

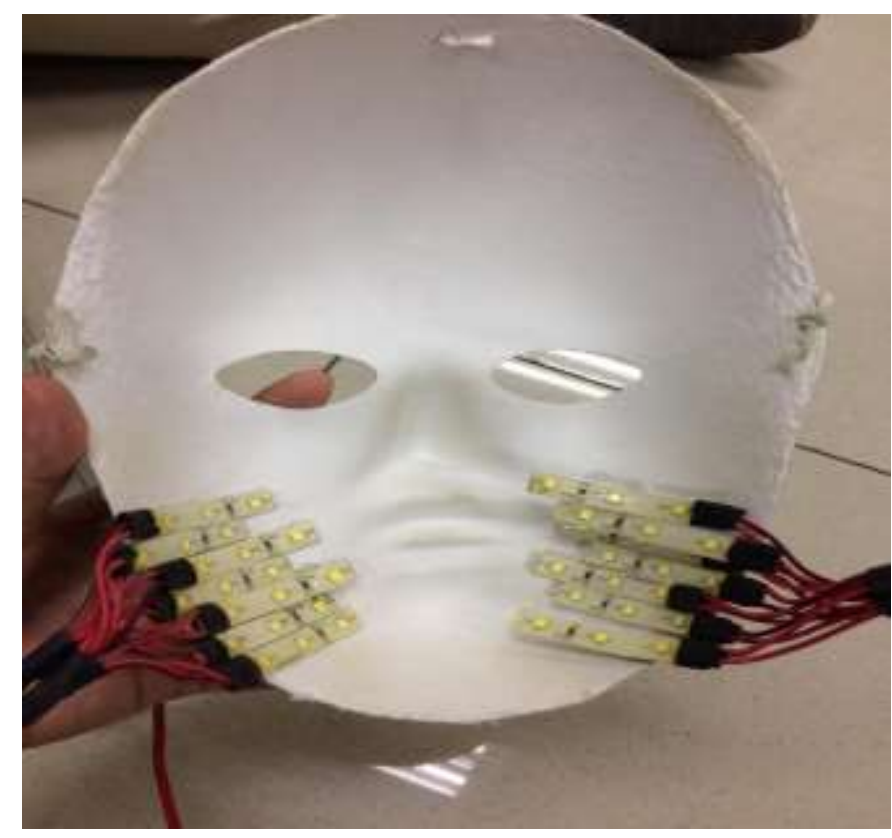

Gambar 4. Bagian Masker Alat Terapi Bell's Palsy

Perangkat terapi Bell's palsy yang dirancang terdiri dari dua unit berbeda seperti yang diilustrasikan dalam Gambar 5. Unit-unitnya adalah: Bagian pertama merupakan kotak utama yang berisi empat tombol pilihan, tombol START untuk menghidupkan perangkat, tombol STOP untuk mematikan perangkat, Tombol UP untuk menaikkan pemilihan waktu dan tombol DOWN untuk menurunkan pemilihan waktu. Bagian kedua adalah masker LED sebagai konduktor yang akan digunakan pada wajah pasien, makser ini terhubung ke kabel di kotak utama yang dapat dipindahkan di sisi kiri atau kanan wajah pasien sesuai kebutuhan. Durasi waktu perangkat dapat diprogram, parameter waktu ini ditampilkan pada LCD untuk umpan balik pengguna dan dikirim ke unit mikrokontroler. 
Catu daya AC ke DC digunakan untuk memberi daya pada sistem yang dirancang. Akhirnya, output dari sistem kontrol dialihkan ke sirkuit driver LED yang menghasilkan daya yang cukup untuk menerangi garis LED.

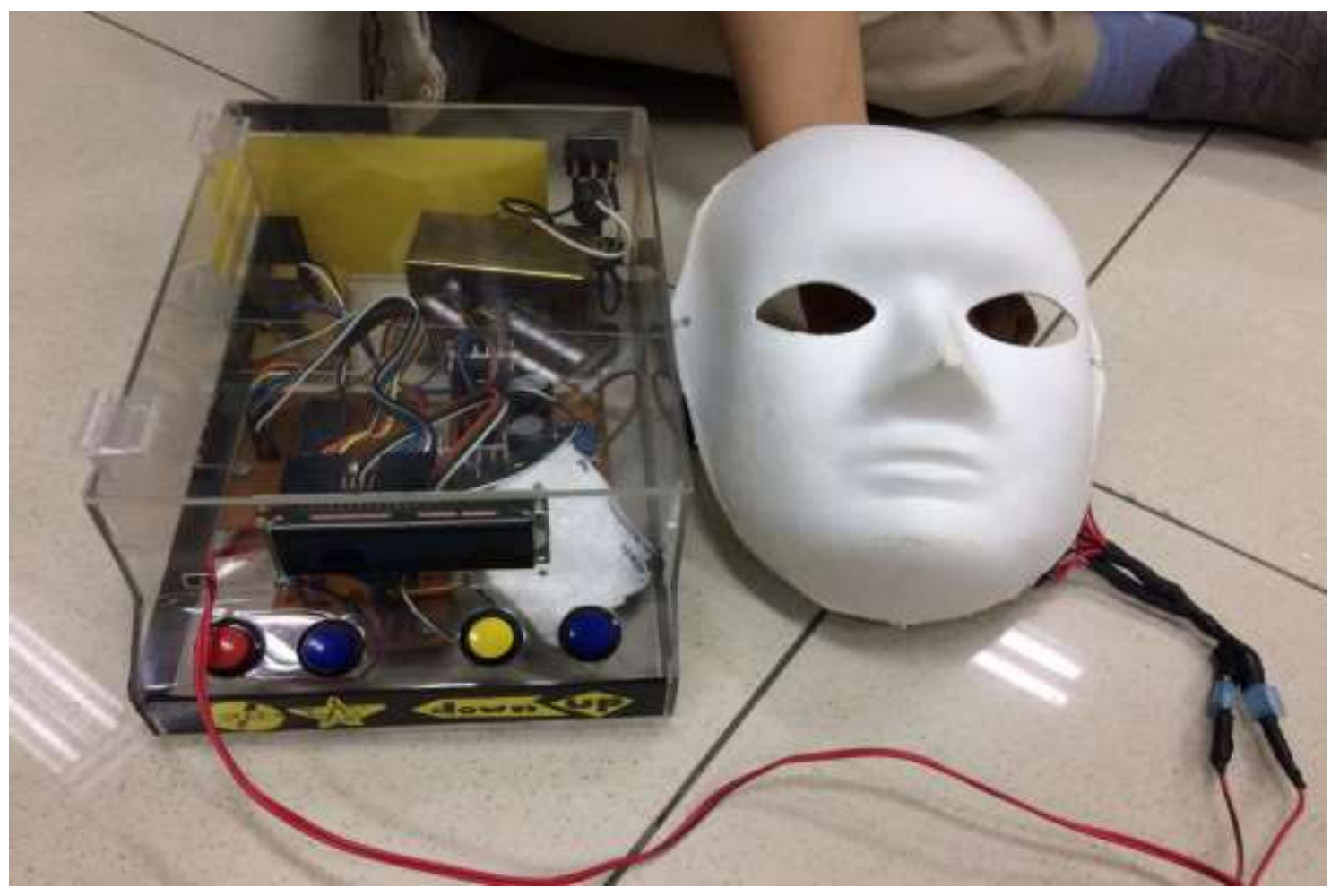

Gambar 5. Alat Terapi Bell's Palsy Berbasis LED Menggunakan Mikrokontroler ATMega 8535

\section{HASIL PENDATAAN DAN PENGUJIAN}

\section{Akurasi Waktu}

Pengujian rangkaian timer bertujuan untuk mengetahui akurasiwaktu dalam proses terapi. Untuk menentukan keakuratan waktu, sistem akan membaca pengaturan waktu dari tombol pemilihan waktu. Pengujian dilakukan selama 15 menit, waktu pada rangkaian kan dibandingkan dengan waktu aktual yang dihitung menggunakan stopwatch. Hasil pengujian ditunjukkan pada tabel 1 
Tabel 1. Hasil Pengujian Rangkaian Waktu Terapi

\begin{tabular}{llll}
\hline $\begin{array}{c}\text { Percobaan } \\
\text { ke- }\end{array}$ & \multicolumn{1}{c}{$\begin{array}{c}\text { Pembacaan pada } \\
\text { LCD }\end{array}$} & \multicolumn{1}{c}{ Pembacaan pada stopwatch } & Penyimpangan \\
\hline 1 & 1 menit & 1 menit & 0 detik \\
\hline 2 & 3 menit & 3 menit, 1 detik & 1 detik \\
\hline 3 & 5 menit & 4 menit, 59 detik & 1 detik \\
\hline 4 & 10 menit & 10 menit, 1 detik & 1 detik \\
\hline 5 & 12 menit & 12 menit, 2 detik & 2 detik \\
\hline 6 & 15 menit & 14 menit, 59 detik & 1 detik \\
\hline
\end{tabular}

Berdasarkan data pada tabel 1 perbedaan terbesar antara waktu yang ditampilkan pada LCD dengan stopwatch adalah 2 detik, sisanya kurang dari itu. Bahkan pada menit pertama, percobaan tidak menunjukkan perbedaan waktu pada LCD dengan stopwatch. Akurasi rangkaian waktu adalah 100\%.

Akurasi Suhu LED

Keakuratan suhu LED dilakukan dengan mengukur suhu pada masker LED menggunakan termometer digital selama 15 menit. Tujuan pengukuran ini adalah untuk mengetahui apakah suhu masker LED cukup stabil. Gambar 5 menunjukkan data stabilitas suhu pada LED. Pengukuran pada menit pertama menggunakan termometer digital terukur suhu $30^{\circ} \mathrm{C}$, suhu kemudian terus naik dan mencapai suhu stabil pada $42^{\circ} \mathrm{C}$ pada menit ke15. Suhu LED yang stabil terbukti dapat meregenerasi sel yang rusak karena penyakit Bell's palsy.(21)

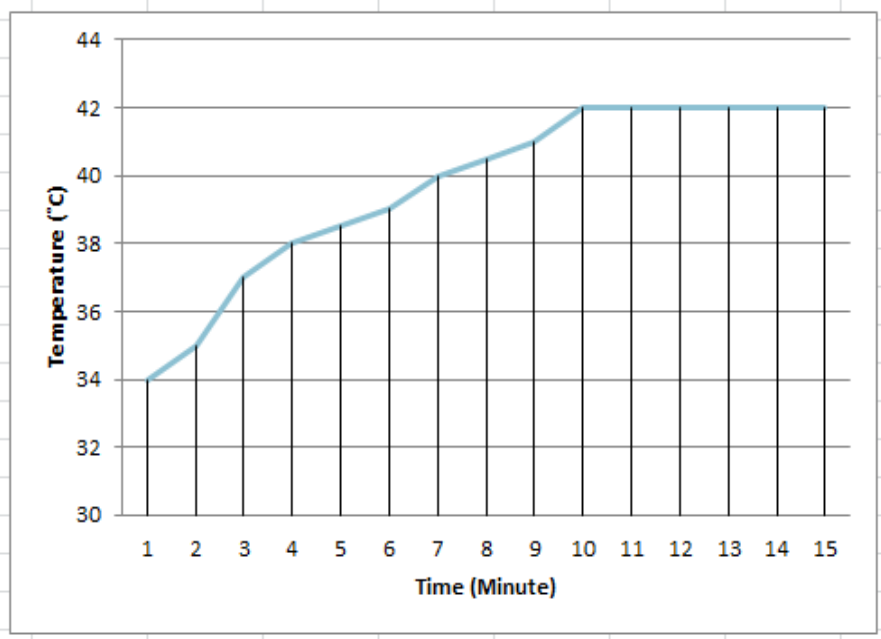

Gambar 5. Pengukuran Suhu Pada Masker LED Menunjukkan Suhu Yang Stabil 


\section{SIMPULAN}

Penelitian ini berhasil membuat perangkat terapi Bell's palsy yang sederhana dan terjangkau menggunakan LED dan mikrokontroler. Di masa depan, penelitian ini dapat terus dikembangkan dengan melengkapi fitur keselamatan bagi pasien. Pengujian lebih lanjut juga dapat dilakukan dalam pengaturan lain sebelum perangkat benar-benar siap untuk digunakan pada pasien

\section{DAFTAR PUSTAKA}

1. Eviston TJ, Croxson GR, Kennedy PGE, Hadlock T, Krishnan A V. Bell's palsy: Aetiology, clinical features and multidisciplinary care. J Neurol Neurosurg Psychiatry. 2015

2. Holland NJ, Weiner GM. Clinical review Recent developments in Bell' s palsy. Br Med J. 2004

3. Teixeira LJ, Valbuza J, Prado GF. Physical therapy for Bell s palsy (idiopathic facial paralysis). Cochrane Database Syst Rev. 2008

4. Lee SY, You CE, Park MY. Blue and red light combination LED phototherapy for acne vulgaris in patients with skin phototype IV. Lasers Surg Med [Internet]. 2007 Feb 1 [cited 2019 Jun 11];39(2):180-8. Available from: http://doi.wiley.com/10.1002/lsm.20412; 2007

5. Orlando Guntinas-Lichius J (DE); Andreas Miiller, Gera (DE); Werner Lindenthaler O (AT). System and Methode for Facial Berve Simulation. Vol. 2. 2014

6. Villani E, Garoli E, Canton V, Pichi F, Nucci P, Ratiglia R. Evaluation of a novel eyelid-warming device in meibomian gland dysfunction unresponsive to traditional warm compress treatment: an in vivo confocal study. Int Ophthalmol. 2015

7. B Cotler H. The Use of Low Level Laser Therapy (LLLT) For Musculoskeletal Pain. MOJ Orthop Rheumatol [Internet]. 2015;2(5). Available from: http://medcraveonline.com/MOJOR/MOJOR-02-00068.php ; 2015

8. Ackroyd R, Kelty C, Brown N, Reed M. The History of Photodetection and Photodynamic Therapy II [Internet]. Vol. 74, Photochemistry and Photobiology. 2001 
[cited 2019 May 24]. Available from: https://pdfs.semanticscholar.org/dc06/68afae5b06169938901027550dfe8e14a088.pdf ; 2019

9. Salgado ASI, Zângaro R a, Parreira RB, Kerppers II, Proofs FP, Starwynn D, et al. LED Light Therapy. Lasers Surg Med. 2010;

10. Peloi LS, Soares RRS, Biondo CEG, Souza VR, Hioka N, Kimura E. Photodynamic effect of light-emitting diode light on cell growth inhibition induced by methylene blue. J Biosci. 2008;

11. Murakami F, Kemmotsu O, Kawano Y, Matsumura C, Kaseno S, Imai M. Diode Low Reactive Level Laser Therapy and Stellate Ganglion Block Compared in the Treatment of Facial Palsy. Vol. 5, Laser Therapy. 2012.

12. Jagdeo J, Austin E, Mamalis A, Wong C, Ho D, Siegel DM. Light-emitting diodes in dermatology: A systematic review of randomized controlled trials. Lasers Surg Med. $2018 ; 50$

13. Kim W-S, Calderhead RG. IS LIGHT-EMITTING DIODE PHOTOTHERAPY (LEDLLLT) REALLY EFFECTIVE? LASER Ther [Internet]. 2011 [cited 2019 May 24];20(3):205-15. Available from: http://joi.jlc.jst.go.jp/JST.JSTAGE/islsm/20.205?from=CrossRef

14. Hirohisa S. Facial Treatment Devices. Vol. 2. United Syayes; 2004.

15. Avci P, Gupta A, Sadasivam M, Vecchio D, Pam Z, Pam N, et al. Low-Level Laser (Light) Therapy (LLLT) in Skin: Stimulating, Healing, Restoring. Semin Cutan Med Surg. 2013

16. Andreas Hilburg O (DE). Light Therapy Device. United States; 2006.

17. Baird C, Stanbridge S. LED Based Phototherapy Device For Photo Rejuvenation of Cells. USA; 2015.

18. Kipp DJ, Springer Jr JF. Portable Phototherapy Device. USA; 2015.

19. Dane, Alexander; Arrianna B. Therapeutic Facial Mask. Vol. 39. United States; 1999.

20. Kohli H, Srivastava S, Sharma SK, Chouhan S, Oza M. Design of Programmable LED Based Phototherapy System. Int J Opt [Internet]. 2019 Jun 2 [cited 2019 Jun 11];2019:1-8. Available from: https://www.hindawi.com/journals/ijo/2019 
21. Weiss R, McDaniel D, Geronemus R, Weiss M, Beasley K, Munavalli G, et al. Clinical Experience with Light-Emitting Diode ( LED ). Dermatol Surg. 2005 